\title{
Nederland en de secularisatie
}

\section{Enige trends in gegevens met betrekking tot levensbeschouwing}

Jos Becker

\section{Samenvatting}

In Nederland neemt het kerklidmaatschap af. De randkerkelijkheid neemt toe. Wat de ontkerkelijking betreft is een plafond van ruim $70 \%$ in zicht. De groei van de islam is onvoldoende om hier verandering in te brengen. Er is weinig behoefte aan een confessionele basis voor maatschappelijke instellingen. Belangrijke onderdelen van het Nederlandse waardenpatroon onttrekken zich aan de invloed van het christelijk geloof. Om deze redenen is het begrip secularisatie achterhaald. Het is hoogstens nog bruikbaar als gemakkelijke aanduiding van een bundel afzonderlijke verschijnselen. Het is bovendien ongenuanceerd. Niet alle religie verdwijnt. Enkele denkbeelden van een algemene strekking, die ook in andere dan de christelijke traditie vallen aan te treffen en in overeenstemming zijn met het individualisme, winnen aanhang. De behoefte aan het irrationele blijft als het geloof in wonderen aanwezig.

\section{Inleiding}

Is er nog reden om in Nederland van secularisatie te spreken nu het aantal buitenkerkelijken zo hoog is geworden en de aanhang van het christelijk geloof zo sterk is teruggelopen? Moet de secularisatie niet als afgesloten worden beschouwd? Deze vragen zijn moeilijk te beantwoorden, omdat er veel verschillende gegevens beschikbaar zijn, die op verschillende manieren geïnterpreteerd kunnen worden. Zo komen Kennedy en Harskamp in hun bijdragen aan de bundel The Dutch and their Gods wat betreft de bruikbaarheid van het secularisatiebegrip tot tegengestelde conclusies, hoewel zij het over hetzelfde land en over dezelfde periode hebben (Kennedy 2005; Harskamp 2005). Ook wij zullen het verlossende woord niet spreken. Wij zijn wel van mening dat het mogelijk is om aan de hand van trends in concrete gegevens enige verheldering te brengen. Eerst geven wij enkele overwegingen, die in vrijwel alle uiteenzettingen over secularisatie zijn terug te vinden.

Secularisatie veronderstelt een uitgangssituatie, waarbij de religie invloed heeft op andere maatschappelijke instituties. Dit standpunt verwijst naar organisaties, vooral naar de organisatie van de religie in kerken. Het 
begrip veronderstelt tevens dat het geloof algemeen wordt aanhangen. Secularisatie treedt op als één van beide aspecten van de uitgangssituatie of beide tegelijk verzwakken. ${ }^{1}$

Een volledig geseculariseerde samenleving is niet goed denkbaar. Levensbeschouwing op grond van een als transcendent ervaren werkelijkheid zal er altijd wel zijn. Verder zullen er altijd mensen zijn die deze in groepsverband willen beleven. We kunnen echter wel zeggen dat naarmate de verzwakking van de religie vertraagt, het begrip secularisatie minder toepasbaar is. Het is de vraag in hoeverre daar in Nederland heden ten dage sprake van is.

Wij zullen ons hier beperken tot de terreinen van het kerklidmaatschap en de kerkgang. Daarnaast besteden wij aandacht aan opvattingen over de betekenis van de kerken voor individu en samenleving en aan meningen over godsdienstige leerstellingen. Daarmee is niet gezegd dat wij andere aspecten van het probleem, zoals de import van niet-christelijke godsdiensten en de mate, waarin alternatieve opvattingen voorkomen, onbelangrijk vinden. Er zullen enige opmerkingen over deze onderwerpen worden gemaakt. Onze gegevens stellen ons echter in staat slechts een beperkt, maar belangrijk deel van het terrein te overzien.

Deze bijdrage is gebaseerd op de publicatie van Becker en De Hart, die bij het Sociaal en Cultureel Planbureau in voorbereiding is. ${ }^{2}$ De cijfers zijn voor het grootste deel afkomstig uit het longitudinale project Culturele Veranderingen in Nederland (CV).

\section{Nederland in internationaal perspectief}

Hoe sterk is Nederland geseculariseerd in vergelijking tot andere landen? De aanhang voor de godsdienst is in ons land stellig geringer dan in bijvoorbeeld de Verenigde Staten, maar welke plaats heeft ons land nu in WestEuropa, waar er van een sterke secularisatie sprake is?

In het begin van de jaren negentig van de vorige eeuw gold Nederland nog als één van de meest geseculariseerde landen in West-Europa (Becker en Vink 1994: 25-33). Later uitgevoerd onderzoek doet vermoeden dat ons land minder uitzonderlijk is geworden. Volgens het European Social Survey (ESS) van 2002 is het kerklidmaatschap in Nederland inderdaad laag te noemen (44\%). In Zweden gaat het echter om een nog lager percentage (30\%), terwijl ook in Duitsland, Frankrijk, België, Groot-Brittannië, Denemarken en Noorwegen een naar verhouding gering deel van de bevolking lid van een kerkgenootschap is (tussen de $50 \%$ en $60 \%$ ).

Van alle Nederlanders gaat $12 \%$ geregeld naar de kerk, dat zijn er ongeveer evenveel als in Groot-Brittannië en in België. Het percentage randkerkelijken (kerkleden, die de kerk onregelmatig of nooit bezoeken) bevindt zich 
maar het percentage was hoger dan in Zweden en in Duitsland. Het was ongeveer even hoog als in Denemarken en Frankrijk (tabel 2). De gegevens zijn afkomstig uit het International Social Survey Project (ISSP). Ook met het oog op algemene levensbeschouwelijke standpunten neemt Nederland dus een middenpositie in.

Tabel 2 Levensbeschouwelijke standpunten naar land, 1991-1998 (in procenten)

\begin{tabular}{|c|c|c|c|c|c|c|c|c|}
\hline & \multirow{2}{*}{$\begin{array}{c}\text { atheïst } \\
1991\end{array}$} & \multicolumn{3}{|c|}{ agnost } & \multicolumn{2}{|c|}{ hogere macht } & \multicolumn{2}{|c|}{ gelooft in Goc } \\
\hline & & 1998 & 1991 & 1998 & 1991 & 1998 & 1991 & 1998 \\
\hline Noorwegen & 10 & 12 & 12 & 12 & 25 & 25 & 53 & 51 \\
\hline Zweden & & 17 & & 18 & & 33 & & 32 \\
\hline Denemarken & & 15 & & 16 & & 24 & & 46 \\
\hline Groot-Brittannië & 10 & 10 & 14 & 16 & 13 & 14 & 64 & 61 \\
\hline Nederland & 16 & 17 & 16 & 12 & 20 & 18 & 48 & 52 \\
\hline Frankrijk & & 19 & & 18 & & 15 & & 48 \\
\hline Duitsland & 30 & 33 & 12 & 12 & 16 & 17 & 42 & 38 \\
\hline Oostenrijk & 4 & 7 & 8 & 8 & 25 & 25 & 63 & 60 \\
\hline Italië & 3 & 4 & 3 & 5 & 9 & 7 & 82 & 84 \\
\hline Spanje & & 9 & & 7 & & 12 & & 72 \\
\hline Rusland & 19 & 20 & 19 & 12 & 21 & 15 & 39 & 54 \\
\hline VS & 2 & 3 & 5 & 5 & 7 & 10 & 86 & 82 \\
\hline
\end{tabular}

Bron: SCP (ISSP'91-'98)

In 1998 geloofde 60\% van de Nederlanders in een leven na de dood, 48\% geloofde in de hemel, $26 \%$ geloofde in de hel, $40 \%$ dacht dat religieuze wonderen mogelijk zijn en $33 \%$ was van mening dat God zich met elk mens persoonlijk bezig houdt. ${ }^{3}$ Internationaal vergeleken vielen deze uitkomsten niet op. Het is wel bijzonder voor Nederland dat de steun voor traditionele leerstellingen toenam. In 1991 geloofde bijvoorbeeld 53\% van alle Nederlanders aan een leven na de dood, in 1998 was dat $60 \%$. Bij enkele andere denkbeelden - hemel, hel en wonderen - deed zich eveneens een stijging van de aanhang voor. Deze veranderingen zijn in de omringende landen uitgebleven. Tijdens de bespreking van de ontwikkelingen in Nederland zullen deze gegevens nog nader aan de orde komen.

Behalve door een beperkte toewending naar religieuze ideeën, valt Nederland op doordat men zich er graag als een religieus mens beschouwt. Volgens de op één na laatste kolom van tabel 1 scoorde $40 \%$ van de Nederlanders hoog toen hen werd gevraagd of zij zichzelf een religieus mens von- 
den. Van de buitenkerkelijken beschouwde 21\% zich als religieus (de laatste kolom van tabel 1). Dit is het hoogste cijfer uit de hele kolom. Waarschijnlijk gaat het hier slechts om het vage idee dat het spirituele een goede zaak is, want het aantal mensen dat de religie als belangrijk voor zijn persoonlijk leven beschouwt, is in Nederland niet bijzonder hoog. Het neemt bovendien af (tabel 4).

Wat bedoelen de mensen nu eigenlijk als zij zichzelf religieus noemen? Het antwoord verschilt voor kerkleden en voor buitenkerkelijken. Een kerklid bedoelt vooral dat hij een trouw kerkganger is, geregeld bidt en geloofswaarheden onderschrijft. Bij de gebedsgenezers houdt hij nog een slag om de arm, maar alternatieve verschijnselen - amuletten, waarzeggers, astrologie - wijst hij af. Religieuze buitenkerkelijken blijken daarentegen 'alleseters' te zijn. Zij gaan weliswaar niet vaak naar de kerk, maar leerstellingen onderschrijven zij opvallend vaak en bovendien hechten zij meer geloof aan alternatieve of paraculturele zaken, vooral aan gebedsgenezers, telepathie, reïncarnatie en bovennatuurlijke krachten. ${ }^{4}$

Het feit dat mensen buiten de kerk staan, toch belangstelling voor christelijke ideeën koesteren, maar ook geneigd zijn alternatieve opvattingen te accepteren, maakt hen tot 'levensbeschouwelijke zoekers'. In 2002 was de buitenkerkelijkheid in Nederland $56 \%$, waarvan $21 \%$ zich als religieus beschouwde. Het ging dus om $12 \%$ van de bevolking (21\% van $56 \%$ ). Dit percentage komt min of meer over een met ander onderzoek, waarbij langs andere weg tot maximaal 16\% zoekers werd geconcludeerd (Becker et al. 1997: 146-148). Wellicht lijkt $12 \%$ aan zoekers niet zoveel, maar internationaal viel het toch op (tabel 3). Een zekere waardering voor religie en een 'open mind' voor het alternatieve lijken typisch Nederlands te zijn.

Tabel 3 Buitenkerkelijkheid, buitenkerkelijken die zich als religieus beschouwen en zoekgedrag in een aantal landen, 2002 (in procenten)

\begin{tabular}{lccc}
\hline & buitenkerkelijken & religieus & Zoeken \\
\hline Noorwegen & 49 & 8 & 4 \\
Zweden & 70 & 10 & 7 \\
Denemarken & 52 & 9 & 5 \\
Groot-Brittannië & 50 & 9 & 5 \\
Nederland & 56 & 21 & 12 \\
België & 51 & 13 & 7 \\
Frankrijk & 50 & 6 & 3 \\
Duitsland & 45 & 6 & 3 \\
Oostenrijk & 30 & 15 & 5 \\
Italië & 23 & 14 & 3 \\
Spanje & 22 & 4 & 9 \\
\hline
\end{tabular}

Bron: SCP(ESS'02) 
Het zou mogelijk kunnen zijn dat kerkverlaters vast blijven houden aan belangrijke kerkelijke rituelen. De mis op kerstavond wordt bijvoorbeeld ook door buitenkerkelijken bezocht. Volgens het World Values Survey (WVS) neemt in Nederland, net als in veel andere landen, de belangstelling voor rituelen af (tabel 4). De belangstelling voor de doop, het kerkelijk huwelijk en de kerkelijke begrafenis is in Nederland het laagste van alle onderzochte landen. Op het terrein van het ritueel is Nederland dus geseculariseerd te noemen.

Tabel 4 Het belang van kerkelijke ceremonieën en het belang van de religie voor het persoonlijk leven naar land, 1990-1999-'02 (in procenten)

\begin{tabular}{|c|c|c|c|c|c|c|c|c|}
\hline & \multicolumn{2}{|c|}{$\begin{array}{l}\text { religie zeer } \\
\text { belangrijk }\end{array}$} & \multirow{2}{*}{$\begin{array}{l}\text { doop } \\
1990 \\
\end{array}$} & \multicolumn{3}{|c|}{ kerkelijk huwelijk } & \multicolumn{2}{|c|}{$\begin{array}{l}\text { kerkelijke } \\
\text { begrafenis }\end{array}$} \\
\hline & 1990 & 1999-'02 & & 1999-'02 & 1990 & 1999-'02 & 1990 & 1999-'02 \\
\hline Noorwegen & 15 & 12 & 66 & & 70 & & 81 & \\
\hline Zweden & 10 & 11 & 56 & 60 & 59 & 62 & 80 & 78 \\
\hline Denemarken & 9 & 8 & 69 & 65 & 64 & 63 & 80 & 80 \\
\hline Groot-Brittannië & 18 & 13 & 65 & 59 & 79 & 69 & 86 & 79 \\
\hline Nederland & 21 & 17 & 47 & 40 & 52 & 46 & 60 & 56 \\
\hline België & 17 & 18 & 75 & 70 & 76 & 70 & 79 & 74 \\
\hline Frankrijk & 14 & 11 & 65 & 61 & 52 & 46 & 60 & 56 \\
\hline Duitsland & 14 & 9 & 59 & 64 & 64 & 68 & 74 & 74 \\
\hline Oostenrijk & 25 & 20 & 87 & 81 & 85 & 76 & 88 & 85 \\
\hline Italië & 31 & 33 & 84 & 89 & 81 & 85 & 86 & 89 \\
\hline Spanje & 21 & 19 & 75 & 78 & 75 & 75 & 76 & 80 \\
\hline Rusland & 12 & 12 & 78 & 75 & 62 & 54 & 74 & 79 \\
\hline VS & 54 & 57 & 57 & & 86 & & 87 & \\
\hline
\end{tabular}

SCP (WVS'90-'02)

\section{Kerklidmaatschap en kerkgang}

Volgens de eigen registraties van een aantal belangrijke kerkgenootschappen, inclusief schattingen van de aantallen islamieten en hindoes, is het aandeel van de kerkleden in de totale bevolking gedaald van ruim $64 \%$ in 1990 tot ruim $45 \%$ in 2005. In de meeste gevallen daalde het aantal aanhangers. Er zijn enkele uitzonderingen op dit algemene beeld, waarvan de islam de belangrijkste is. Het aantal islamieten steeg van 458000 in 1990 tot 944000 of bijna $6 \%$ van de bevolking in 2005. De aanhang van het hindoeissme nam 
toe van 61000 tot 99000 . Er vielen meestal geringe stijgingen te constateren bij een aantal orthodox-protestantse kerken. De aanhang van de Pinkstergemeenten en van de Evangelische gemeenten bleef min of meer gelijk. Deze conclusie wijkt af van het gangbare idee dat juist deze groeperingen groeien. Het gaat mogelijk om het gevolg van gebrekkige registratie. ${ }^{6}$ Deze stijgingen, zelfs die bij de islam, zijn onvoldoende om het tij van de ontkerkelijking te keren. Het aantal christenen onder de migranten, aangeduid als de nieuwkomers of als de 'Bijlmerkerken' wordt wel op 850000 geschat, verdeeld over ruim 1000 genootschappen en groeperingen. Het genoemde aantal aanhangers is vermoedelijk te hoog. Zelfs als het accuraat zou zijn, weegt het niet op tegen de ontkerkelijking.

Enquêtes wijzen eveneens op een aanzienlijke ontkerkelijking, waarbij een langere termijn kan worden overzien. Volgens het onderzoek 'Riskante gewoonten' van Gadourek uit 1958 noemde 24\% van de Nederlanders zich toen buitenkerkelijk. In 2004 was de buitenkerkelijkheid gestegen tot 64\%. Het aandeel van de rooms-katholieken nam sinds 1958 af van $42 \%$ naar $17 \%$. Het aandeel van de Nederlands-hervormden zakte van $23 \%$ naar $6 \%$, dat van de gereformeerden ging van $8 \%$ naar $4 \%$. Alleen de aanhang van de 'andere kerkgenootschappen' nam toe, van 3\% naar 5\% (figuur 1).

Tussen 1958 en 1980 steeg het percentage buitenkerkelijken met 26 procentpunten, namelijk van 24 naar 50. Tussen 1980 en 2004 verliep de stijging in een trager tempo: de toename bedroeg 14 procentpunten. Tussen 1958 en

Figuur 1 De kerkelijke gezindte, 1958-2004 (in procenten)

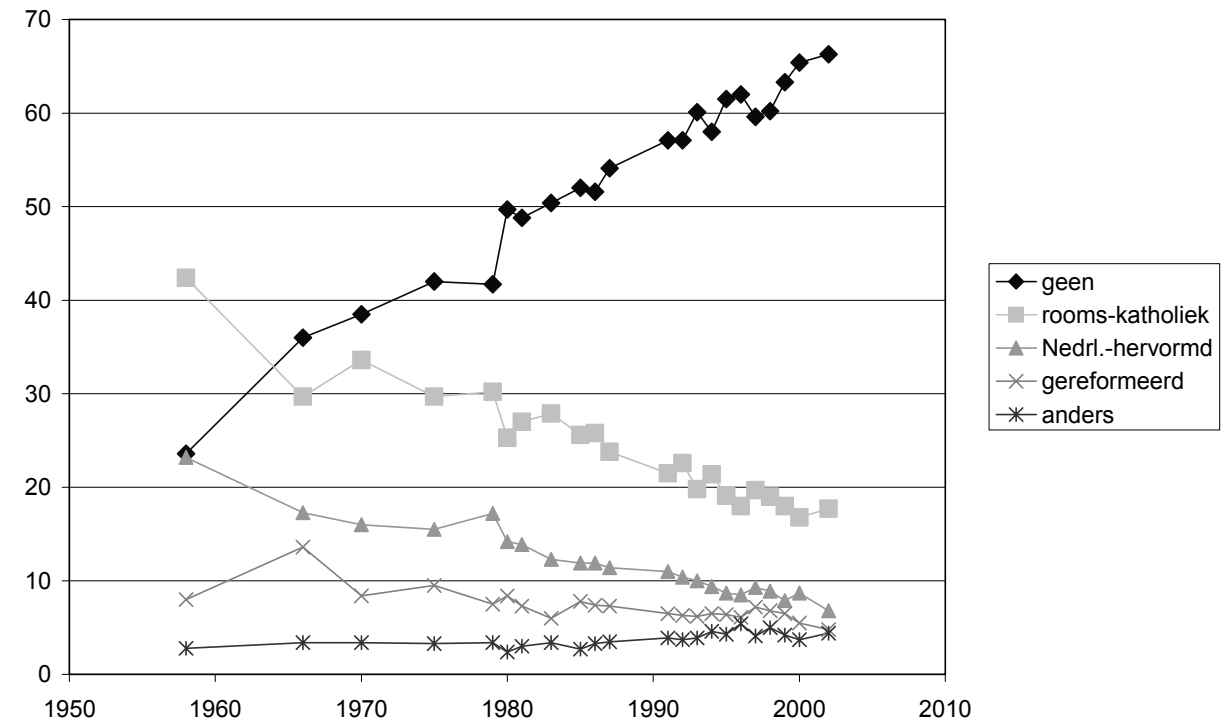

Bron: Riskante gewoonten 1958; God in Nederland 1966; Progressiviteit en conservatisme 1970; SCP (CV 1975-2004). 
2004 is de buitenkerkelijkheid met gemiddeld $0,8 \%$ gestegen. $^{7}$ De consequente en sterke stijging van de buitenkerkelijkheid wijst er niet op dat buitenkerkelijken naar de kerken terugkeerden. Een eerder uitgevoerde analyse leverde dezelfde conclusie op (Becker et al 1997: 61-65).

Er bestaat een verband tussen de mate van buitenkerkelijkheid en de generatie, waartoe de ondervraagde behoort. Hoe jonger deze is, hoe hoger de buitenkerkelijkheid. Onder de jongere generaties is de buitenkerkelijkheid bovendien sneller gegroeid dan onder de oudere. De naoorlogse generaties (geboren in 1945 of in een later jaar) verlieten de kerken veel vaker dan de vooroorlogse. De ontwikkelingen wijzen er op dat de buitenkerkelijkheid een plafond nadert. De generatie met een geboortejaar tussen 1975 en 1988, de oudste leden waren in 200429 jaar, de jongste leden waren 16 jaar, had de hoogste buitenkerkelijkheid van alle onderscheiden generaties. ${ }^{8}$ Tussen 1990 en 2005 steeg het percentage niet, het daalde zelfs en wel van ongeveer $80 \%$ in 1990 tot ongeveer 70\% in 2004. Mogelijk representeert deze 70\% een bovengrens in de buitenkerkelijkheid (figuur 2).

Figuur 2 De buitenkerkelijkheid naar generatie, 1966-2004 (in procenten)

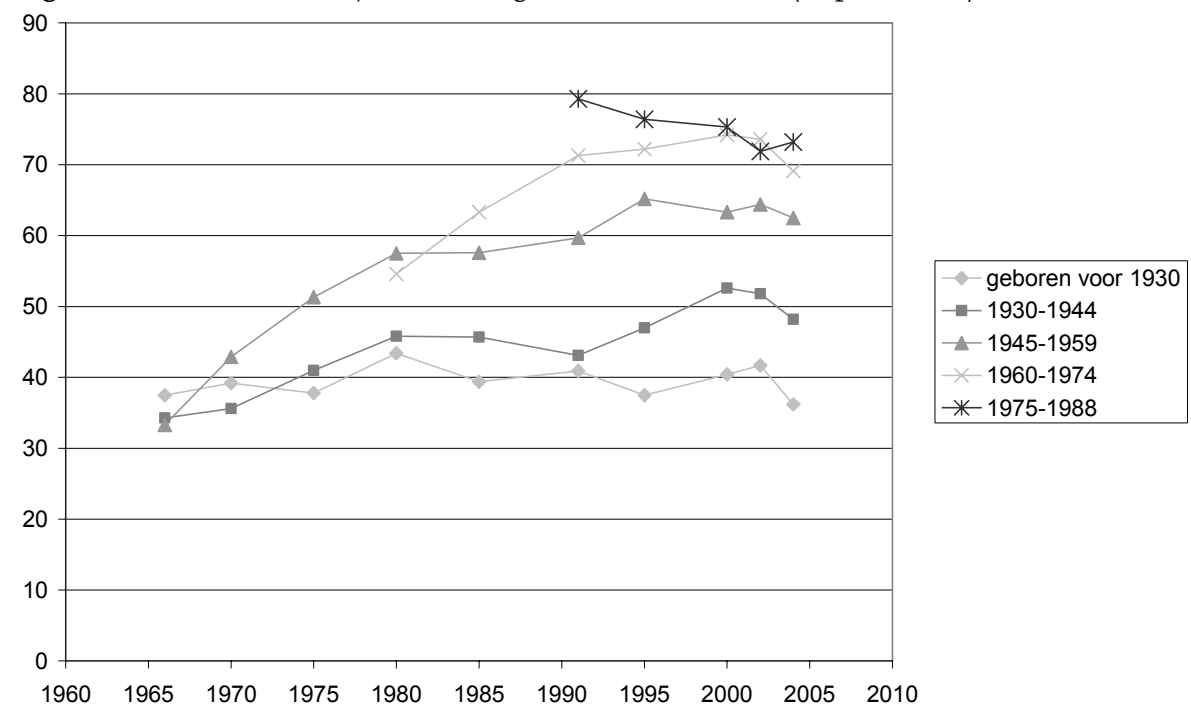

Bron: God in Nederland 1966; Progressiviteit en conservatisme 1970; SCP (CV'75-'04).

De geregelde kerkgang onder de kerkleden - geregeld is hier tenminste eenmaal per 14 dagen - is sinds 1970 consequent gedaald (figuur 3). Te beginnen met het jaar 2000 lijkt zich onder de Nederlands-hervormden en de gereformeerden weer stijging voor te doen. Bij de rooms-katholieken blijft het misbezoek dalen. Tussen 1970 en 2004 is de randkerkelijkheid - men is nog wel lid maar gaat zelden of nooit - tot een aanzienlijk niveau gestegen. Van 
de gereformeerden bezocht in 2004 bijna $40 \%$ de godsdienstoefeningen onregelmatig of niet, bij de Nederlands-hervormden was dat $50 \%$ en bij de rooms-katholieken $80 \%$.

Figuur 3 Geregelde kerkgang (tenminste één maal per veertien dagen naar kerkgenootschap, 1970-2004 (in procenten)

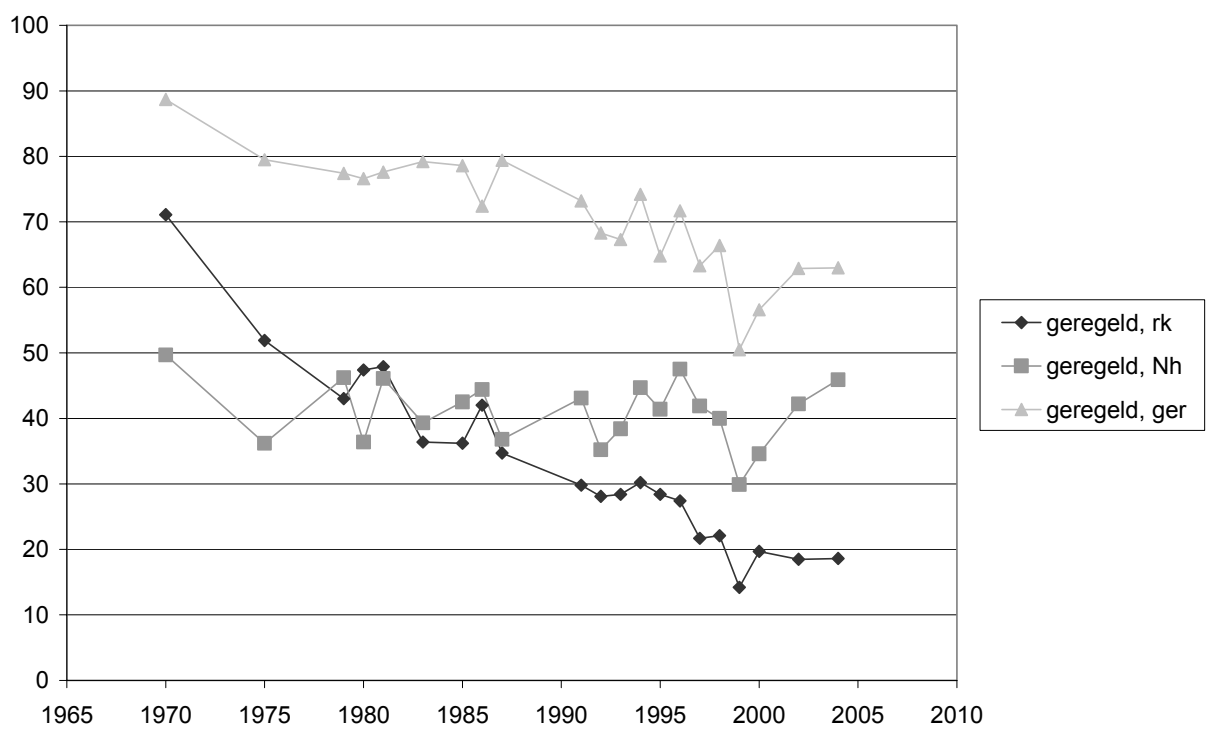

Bron: Progressiviteit en conservatisme 1970; SCP (CV'75-'04).

Hoe zal het in de toekomst gaan met het kerklidmaatschap? De ontwikkelingen bij de christelijke gezindten zijn tot 2020 doorgetrokken met behulp van een logistisch regressiemodel. Dit model gaat ervan uit dat groei - anders dan bij lineaire extrapolatie - op een gegeven moment gaat vertragen. Alle kerkleden, die vatbaar voor ontkerkelijking zijn, zullen op den duur de kerk hebben verlaten, zodat de buitenkerkelijkheid wel langzamer moet groeien of moet stagneren. Het buigpunt, waarbij deze ontwikkeling zichtbaar wordt, ligt bij het jaar 2000.

De steekproeven bevatten te weinig islamieten om er conclusies aan te verbinden. ${ }^{9}$ Hun aantal is geprognosticeerd met behulp van de Allochtonenprognose van het CBS, waarin de aantallen minderheden zijn weergegeven naar het land van herkomst. Er is aangenomen dat het percentage islamieten in het land van herkomst hetzelfde is als onder de migranten, tenzij er reden was om van deze veronderstelling af te wijken. ${ }^{10}$ In 2020 zou ruim 7,5\% van de bevolking islamiet kunnen zijn. Enerzijds is dit percentage lager dan wat men op grond van de stormachtige ontwikkeling uit het verleden zou vermoeden. Anderzijds is het resultaat in overeenstemming met de te verwach- 
ten afvlakking van de migratie. De conclusie geldt onder de veronderstelling dat weinig of geen islamieten hun geloof in de komende decennia zullen los laten.

De resultaten als geheel zijn vermeld in tabel 5 . Rekeninghoudend met de islam in Nederland was de buitenkerkelijkheid in 2000 62\%, in 20 jaar tijd zou daar nog $10 \%$ bij kunnen komen, zodat in 2020 72\% van de bevolking buitenkerkelijk zou kunnen zijn. Er zijn dan nog twee omvangrijke kerken of groepen over: rooms-katholieken (10\%) en islamieten (8\%). Daarnaast zal er sprake zijn van een substantiële groep van kleine genootschappen en gezindten, die sterk van elkaar verschillen. De aanhang van de Protestantse Kerk Nederland (PKN) kan nog afzonderlijk worden onderscheiden, maar zij zal dalen van $12 \%$ in 2000 tot $4 \%$ in 2020 .

Op grond van de vrijwel consequente daling in de geregelde kerkgang zullen de overblijvende leden de kerk ongeregeld bezoeken. Protestanten blijven vermoedelijk trouwere kerkgangers dan de rooms-katholieken. De binding aan het kerkgenootschap zou dan vooral in de opvattingen tot uiting moeten komen. Hierover handelt de volgende paragraaf.

Tabel 5 Waargenomen en geschatte aandelen van de grote gezindten in de Nederlandse bevolking, 2000-2020 (in procenten)

\begin{tabular}{lccccc}
\hline & $\begin{array}{c}2000 \\
\text { waargenomen } \\
\text { zonder islam }\end{array}$ & $\begin{array}{c}\text { waargenomen } \\
\text { met islam }\end{array}$ & geschat & geschat & geschat \\
\hline geen & 65 & 62 & 62 & 68 & 72 \\
rooms-katholiek & 17 & 16 & 17 & 13 & 10 \\
Nederlands- & 9 & 7 & 7 & 4 & 2 \\
hervormd & 6 & 5 & 5 & 3 & 2 \\
gereformeerd & 0 & 5 & 5 & 6 & 8 \\
islam & 4 & 3 & 3 & 5 & 7 \\
overig & 100 & 100 & 100 & 100 & 100 \\
totaal & & & & & \\
\hline
\end{tabular}

Bron: SCP (CV 2000); CBS.

\section{Opvattingen over kerk en godsdienst}

\subsection{Opvattingen over de kerken}

De Nederlanders stellen minder vertrouwen in de kerken dan in vele andere maatschappelijke instituties. In 2004 bijvoorbeeld had 60\% vertrouwen in de kerken, terwijl 90\% vertrouwen in het onderwijs uitsprak (Dekker et al. 2004: 17-25). Het is de vraag wat wij hier onder vertrouwen moeten verstaan, om- 
dat instituties zo slecht vergelijkbaar zijn. Kerken vervullen nu eenmaal andere functies dan onderwijsinstellingen. Bovendien is het onderwijs voor elke Nederlander relevant, terwijl de kerken vooral voor de kerkleden belang hebben. Waarschijnlijk representeert vertrouwen een gegeneraliseerde positieve attitude. De mening van het publiek over de mogelijke invloed van de religie op andere maatschappelijke instellingen is daarom van meer belang. Het idee dat instituties of organisaties een confessionele basis zouden moeten hebben is, met uitzondering van het onderwijs, vrijwel verdwenen. In het project Culturele Veranderingen in Nederland zijn de meningen over verzuilde instellingen lange tijd gevolgd, maar toen de steun voor de verzuiling sterk was afgenomen, zijn niet alle reeksen voortgezet. In 1996 vond $20 \%$ dat een omroepvereniging een confessionele basis behoorde te hebben. Gezien het succes van de Evangelische Omroep is het niet verwonderlijk dat de adhesie hier nog hoog uitviel. In hetzelfde jaar vond $16 \%$ een jeugdvereniging op confessionele basis gewenst, $11 \%$ vond dat van een vakvereniging en $4 \%$ stond sportverenigingen op confessionele grondslag voor.

$\mathrm{Bij}$ het onderwijs en vermoedelijk eveneens bij de politieke partijen speelt vermoedelijk ook nog mee dat het veel mensen niet uitmaakt wie een bepaalde functie vervult, als het maar naar wens gebeurt (tabel 6). In het geval van het onderwijs spraken vrij veel respondenten geen voorkeur uit. Kennelijk waren andere schoolkeuzemotieven belangrijker dan de aard van de school. In het geval van de politieke partij vonden weinig ondervraagden, ook de kerkleden, dat een politieke partij een godsdienstige grondslag moest hebben. Toch trekt het CDA veel stemmers. Waarschijnlijk bestaat er behoefte aan een brede middenpartij, ongeacht het levensbeschouwelijk karakter, tenminste zolang het godsdienstige principe maar niet al te sterk wordt geaccentueerd.

Tabel 6 Opvattingen over de wenselijkheid van een godsdienstige grondslag voor de lagere school en voor een politieke partij voor allen en voor kerkleden, 2002 (in procenten)

\begin{tabular}{lcc}
\hline & allen & kerkleden \\
\hline lagere school & & \\
Openbaar & 37 & 15 \\
maakt niet uit & 29 & 24 \\
godsdienstige grondslag & 34 & 61 \\
politieke partij & & \\
geen godsdienstige grondslag & 89 & 74 \\
wel godsdienstige grondslag & 11 & 26 \\
\hline
\end{tabular}

Bron: SCP (CV 2002) 
Hebben de kerken nog invloed op het persoonlijk leven van de mensen? Deze invloed is niet geheel afwezig, maar beperkt van aard (tabel 7). Bijna de helft van de bevolking geloofde in 1999 dat de kerken de geestelijke behoeften van de mens konden vervullen. Onder de kerkleden was dat met $61 \%$ niet zoveel meer. Wij vinden deze percentages aan de lage kant, omdat zingeving de kernfunctie van de kerken is. Voor velen zijn de kerken niet langer een baken in het geval van problemen met de moraal, in het gezin en op het sociale vlak. Ongeveer de helft van de kerkleden ontkent hierin houvast aan de kerken te hebben. Het grootste deel van de buitenkerkelijken en van de bevolking als geheel ziet hier geen rol voor de kerken weggelegd.

Tabel 7 De Nederlandse kerken hebben een adequaat antwoord op een aantal behoeften en problemen naar kerklidmaatschap, 1999 (in procenten)

\begin{tabular}{lccc}
\hline & allen & buitenkerkelijken & kerkleden \\
\hline $\begin{array}{l}\text { geestelijke behoeften van de } \\
\text { mens }\end{array}$ & 49 & 37 & 61 \\
$\begin{array}{l}\text { morele problemen van mensen } \\
\text { problemen rond het gezins- }\end{array} \quad 36$ & 21 & 51 \\
$\quad$ leven & 31 & 16 & 47 \\
sociale problemen van het land & 37 & 22 & 53 \\
\hline
\end{tabular}

Bron: WVS ('99-'02)

Tabel 8 brengt de relaties tussen het christelijk geloof en andere waarden in beeld. Het christelijk geloof is geoperationaliseerd met de opvattingen over het bestaan van God, het bestaan van een leven na de dood en de zingeving van het leven met een verwijzing naar God. De gegevens zijn afkomstig uit het onderzoek Sociaal Culturele Ontwikkelingen in Nederland (SOCON). Rekeninghoudend met de operationalisering van de andere waardencomplexen valt te concluderen dat het christelijk geloof samenging met een terughoudend standpunt ten aanzien van burgerlijke vrijheden, de gelijke positie van man en vrouw en vooral de actieve ingreep in leven en dood, zoals bij abor-

Tabel 8 Samenhangen tussen het christelijk geloof en waardenoriëntaties, 2000 (in Pearsoncorrelaties)

\begin{tabular}{ll}
\hline cultureel conservatisme & 0,56 \\
familiale burgerlijkheid & 0,26 \\
economische burgerlijkheid & 0,05 \\
maatschappijkritiek & 0,09 \\
economisch conservatisme & $-0,02$ \\
Hedonisme & $-0,18$ \\
\hline
\end{tabular}

Bron: Felling 1999: 58 
tus en euthanasie (cultureel conservatisme). Christenen neigden tot een sterke oriëntatie op het gezin. Verder namen zij het leven serieus op, want het idee dat de mens zoveel mogelijk van zijn leven moet genieten, wezen zij af (hedonisme). De negatieve correlatie is overigens vrij laag. Dat men vooral vooruit moet komen in het leven, dat geld belangrijk is en dat maatschappelijke ongelijkheid bestreden moet worden, vonden de christenen niet in het bijzonder (economische burgerlijkheid en maatschappijkritiek). Het beeld is vertrouwd: veel van onze waarden ontrekken zich aan de invloed van de religie.

Wij besluiten deze paragraaf met de opvatting van de kerkleden over de leefregels, die hun eigen kerk hen stelt. Niet dat er daar nog veel van zijn. De kerken hebben die regels aanzienlijk versoepeld of afgeschaft. Strikte geboden hoort men alleen nog van de katholieke bisschoppen (met weinig resultaat) en van orthodox protestantse zijde (een kleine groep). Toch zijn de kerkleden zich vrijer tegenover de overgebleven leefregels gaan opstellen (tabel 9). In 1966 zei 51\% van hen dat men zich aan alle regels van de eigen kerk diende te houden, in 2002 was dat 18\%. Tussen 2002 en 2004 steeg het percentage van gezagsgetrouwen plotseling naar $28 \%$. Deze verandering zou het gevolg kunnen zijn van selectie. De ontkerkelijking is nu zover voortgeschreden dat de overtuigden onder de kerkleden getalsmatig een steeds groter aandeel gaan krijgen, hetgeen in de meningen van alle kerkleden tot uiting komt. De selectie komt vooral onder de jongere kerkleden naar voren. De verstrakking van de opvattingen zette zich namelijk in bij degenen, die na 1960 waren geboren. De jongeren hebben de kerken het snelste verlaten, zodat een eventuele selectie vooral onder hen tot uiting komt.

Tabel 9 De mate, waarin men zich aan alle regels van de eigen kerk moet houden onder kerkleden, 1966-2004 (in procenten)

\begin{tabular}{lccccccc}
\hline & 1966 & 1975 & 1986 & 1996 & 2000 & 2002 & 2004 \\
aan alle regels houden & 51 & 28 & 20 & 21 & 18 & 18 & 28 \\
hangt ervan af & 20 & 33 & 33 & 25 & 31 & 34 & 23 \\
niet aan alle regels houden & 29 & 38 & 47 & 55 & 50 & 48 & 49 \\
\hline
\end{tabular}

Bron: God in Nederland 1966; Progressiviteit en Conservatisme 1970; SCP (CV'75-'04)

\subsection{Verandering van opvattingen}

Tussen 1966 en 1991 zijn de kerkleden religieuze leerstellingen minder gaan onderschrijven. De grootste terugval vond plaats tussen 1966 en 1975. Daarna was er gedurende ruim 20 jaar sprake van een langzame afkalving, maar 
na 1991 steeg de instemming weer. ${ }^{11}$ Tabel 10 toont de laatst genoemde verandering. Omdat de betreffende vragen in een later stadium van Culturele Veranderingen in Nederland aan de gehele steekproef werden voorgelegd, waren er ook gegevens van de buitenkerkelijken en van alle Nederlanders beschikbaar.

De veranderingen zijn over het algemeen gering. $\mathrm{Zij}$ ontlenen vooral hun belang aan het feit dat zij verschillen van die in de voorafgaande lange periode van daling. Bij een aantal opvattingen trad tussen 1991 en 1996 een stijging in adhesie op, daarna daalde deze in enige mate of bleef ze gelijk. Verder verschilt het beeld per mening, waarbij er twee uitsprongen. Steeds minder mensen geloofden dat Adam en Eva werkelijk hadden bestaan, steeds meer mensen hielden religieuze wonderen voor mogelijk. De letterlijke interpretatie van het scheppingsverhaal vond dus minder aanhang, maar de mensen wilden wel aannemen dat er meer in de wereld kon gebeuren dan de wetenschap voor mogelijk hield.

De resultaten van de kerkleden zijn als volgt. De verschillen tussen 1991 en 2002 zijn in procentpunten tussen haakjes weergegeven. De kerkleden gingen nog wat meer geloven in een leven na de dood $(+3)$, in de hemel $(+8)$, in de hel $(+8)$ en in wonderen $(+14)$. Zij vonden het minder zinvol om voor zichzelf te bidden (-7). De instemming met de interpretatie van de bijbel als volledig Gods woord bleef gelijk, net als het geloof aan de duivel (-2). Het geloof aan het historisch bestaan van Adam en Eva nam duidelijk af (-14). ${ }^{12}$

Buitenkerkelijken onderschreven de leerstellingen vanzelfsprekend veel minder dan de kerkleden. Voorzover zij wel iets voor de leerstellingen voelden, volgden de veranderingen vrijwel hetzelfde patroon als bij de kerkleden. Ook de buitenkerkelijken gingen meer denken dat er na dit leven nog iets kwam (+5). Zij geloofden vaker in de hemel $(+8)$, aan wonderen $(+16)$ en zelfs aan de hel $(+5)$. De laatste uitkomst kan echter slechts een bottom-effect zijn, omdat zeer weinig buitenkerkelijken geloof aan het bestaan van een hel hechtten. Het toch al geringe geloof aan Adam en Eva nam verder af (-5). De aanhang voor de visie op de bijbel als Gods woord (-2), de visie op het gebed als zinvol en het geloof aan de duivel bleven ongeveer gelijk. De ontwikkelingen in de opvattingen van de buitenkerkelijken sporen met de conclusie dat er internationaal gesproken veel zoekers onder hen zijn $(12 \%$, zie paragraaf 2). Zij zochten, zoals werd vermeld, echter niet alleen binnen het christendom, maar ook daarbuiten.

Het is niet eenvoudig om een lijn in de veranderingen te ontwaren. Zeer in het algemeen gaat het hier vermoedelijk om een verandering van de tijdgeest, omdat de ontwikkelingen zowel bij de kerkleden als bij de buitenkerkelijken plaats vonden. Inhoudelijk gezien werden leerstellige ideeën (vooral Adam en Eva en de meer strikte interpretatie van de bijbel) losgelaten, terwijl algemene opvattingen, die niet alleen christelijk geïnterpreteerd hoefden te 
Tabel 10 De steun voor leerstellingen onder kerkleden, buitenkerkelijken en alle Nederlanders, 1991-2002 (in procenten)

\begin{tabular}{|c|c|c|c|c|}
\hline & 1991 & 1996 & 2002 & $1991-2002$ \\
\hline \multicolumn{5}{|l|}{ leven na de dood } \\
\hline kerkleden & 69 & 76 & 72 & +3 \\
\hline buitenkerkelijken & 32 & 39 & 37 & +5 \\
\hline allen & 48 & 53 & 49 & +1 \\
\hline \multicolumn{5}{|l|}{ de hemel } \\
\hline kerkleden & 86 & 90 & 92 & +6 \\
\hline buitenkerkelijken & 17 & 23 & 25 & +8 \\
\hline allen & 40 & 43 & 40 & 0 \\
\hline \multicolumn{5}{|l|}{ de hel } \\
\hline kerkleden & 40 & 46 & 48 & +8 \\
\hline buitenkerkelijken & 4 & 7 & 9 & +5 \\
\hline allen & 14 & 17 & 18 & +4 \\
\hline \multicolumn{5}{|l|}{ de duivel } \\
\hline kerkleden & 51 & 47 & 49 & -2 \\
\hline buitenkerkelijken & 7 & 7 & 7 & 0 \\
\hline allen & 19 & 18 & 17 & -2 \\
\hline \multicolumn{5}{|l|}{ Adam en Eva } \\
\hline kerkleden & 56 & 54 & 42 & -14 \\
\hline buitenkerkelijken & 19 & 16 & 14 & -5 \\
\hline allen & 36 & 31 & 24 & -12 \\
\hline \multicolumn{5}{|c|}{ bijbel woord van God } \\
\hline kerkleden & 62 & 69 & 62 & 0 \\
\hline buitenkerkelijken & 17 & 18 & 15 & -2 \\
\hline allen & 37 & 38 & 31 & -6 \\
\hline \multicolumn{5}{|l|}{ bidden zinvol } \\
\hline kerkleden & 83 & 83 & 76 & -7 \\
\hline buitenkerkelijken & 19 & 24 & 19 & 0 \\
\hline allen & 47 & 47 & 39 & -8 \\
\hline \multicolumn{5}{|l|}{ Wonderen } \\
\hline kerkleden & 53 & 64 & 67 & +14 \\
\hline buitenkerkelijken & 15 & 24 & 31 & +16 \\
\hline allen & 31 & 40 & 43 & +12 \\
\hline
\end{tabular}

Bron: SCP (CV'91-’02) 
worden, aanhang wonnen of qua adhesie op hetzelfde peil bleven. Met uitzondering van het geloof aan de hel zijn dat ook de meer positieve of 'aardige' kanten van het geloof. De teruggang bij het belang van het bidden blijft moeilijk inpasbaar. Deze activiteit is toch als positief voor de mens te duiden. Mogelijk heeft de teruggang van het idee dat God elk mens persoonlijk aandacht schenkt hier iets mee van doen.

Het is verleidelijk de veranderingen als een uiting van individualisme te zien, waarin het heil van de mens centraal staat. De christelijke God, die over ieder waakt, is er misschien niet meer, maar in de kosmos komt het wel goed met de mens. Er kunnen zelfs buiten de natuurlijke orde om mooie dingen voor hem gebeuren. Het toegenomen geloof in de hel spoort niet met deze interpretatie. Het immers moeilijk voorstelbaar dat individualistisch ingestelde mensen gaan geloven dat het kostbare zelf eeuwig zal branden. Het gaat echter slechts om één mening, die niet aan de veronderstelling beantwoordt. Bovendien verandert het geloof in de duivel niet. Er is dus sprake van een toewending naar de religie, maar alleen voorzover die niet specifiek christelijk is en mogelijk met de dominante trend van het optimistisch individualisme kan worden verzoend.

Tabel 11 De instemming met een aantal geloofspunten naar generatie onder kerkleden, 1991-2002 (in procenten)

\begin{tabular}{lllll}
\hline & 1991 & 1996 & 2002 & $1991-2002$ \\
\hline Adam en Eva & 56 & 54 & 42 & -14 \\
alle kerkleden & 66 & 52 & 46 & -21 \\
geboren voor 1930 & 57 & 50 & 36 & -21 \\
$1930-1944$ & 55 & 48 & 36 & -19 \\
$1945-1959$ & 56 & 64 & 56 & 0 \\
$1960-1988$ & & & & \\
bijbel woord van God & & & & \\
alle kerkleden & 62 & 69 & 62 & 0 \\
geboren voor 1930 & 70 & 68 & 66 & -5 \\
$1930-1944$ & 57 & 69 & 61 & 4 \\
$1945-1959$ & 63 & 67 & 64 & 0 \\
$1960-1988$ & 62 & 72 & 62 & 0 \\
bidden is zinvol & & & & \\
alle kerkleden & & & & \\
geboren voor 1930 & 83 & 83 & 76 & -7 \\
$1930-1944$ & 88 & 84 & 87 & -1 \\
$1945-1959$ & 85 & 85 & 77 & -8 \\
$1960-1988$ & 85 & 80 & 75 & -10 \\
\hline
\end{tabular}

Bron: SCP (CV'91-'02) 
Zijn de ontwikkelingen onder de kerkleden nu ook een uiting van selectie, zoals wij eerder bij de acceptatie van de kerkelijke leefregels hebben verondersteld? De omstandigheid dat de veranderingen bij de kerkleden en de buitenkerkelijken ongeveer dezelfde zijn, wijst eerder op tijdsinvloed dan op de werkzaamheid van selectie. Toch wees de toegenomen acceptatie van kerkelijke regels onder jonger kerkleden op het laatste. Ook om een andere reden menen wij dat de veranderingen in de opvattingen van de kerkleden niet uitsluitend op het conto van de tijd kunnen worden geschreven. Zelfs onder de kerkleden liep de aanhang voor het scheppingsverhaal en het gebed terug en bleef de aanhang voor een strikte interpretatie van de bijbel gelijk. De jongste generatie kerkleden hield echter het meest aan deze ideeën vast. Zij bleef even orthodox denken, terwijl zij als zij alleen maar vatbaar voor de tijdgeest waren geweest, juist voorop hadden moeten lopen (tabel 11). Hier in is een aanwijzing voor de werkzaamheid van selectie gelegen, die naast de tijdgeest een rol speelt.

Wij sluiten de beschouwing over de verandering van opvattingen af met een opmerking over de trends onder alle Nederlanders (tabel 10). Op het eerste gezicht zijn deze zwak te noemen, maar onder de oppervlakte doet zich toch een verandering voor. Wij geven deze keer het beeld, gedifferentieerd naar leeftijd, weer (tabel 12). Aanvankelijk was de situatie, zoals men mag verwachten. De oudste groep (51 jaar en ouder) hield meer vast aan enkele denkbeelden dan de andere categorieën. In 1991 is het verband met leeftijd omgekeerd. De 16-30-jarigen raakten meer overtuigd, juist de ouderen werden sceptisch. De gevoeligheid voor algemene religieuze ideeën neemt dus vooral toe onder de jongeren.

Tabel 12 De aanhang voor geloofspunten naar leeftijd, 1985-2002 (in procenten)

\begin{tabular}{lccccc}
\hline & 1985 & 1991 & 1996 & 1998 & 2002 \\
\hline $16-30$ & 45 & 48 & 54 & 59 & 56 \\
$31-50$ & 45 & 47 & 53 & 52 & 49 \\
51 en ouder & 59 & 49 & 53 & 54 & 43 \\
$16-30$ & 36 & 36 & 40 & & 47 \\
$31-50$ & 41 & 40 & 41 & & 41 \\
51 en ouder & 56 & 43 & 50 & & 36 \\
$16-30$ & 12 & 13 & 18 & & 22 \\
$31-50$ & 16 & 13 & 16 & & 18 \\
51 en ouder & 21 & 18 & 20 & & 14 \\
$16-30$ & & 29 & & 43 & 49 \\
$31-50$ & & 29 & & 38 & 41 \\
51 en ouder & & 37 & & 40 & 41 \\
\hline
\end{tabular}

Bron: SCP (CV'85-'02) 


\section{Slotbeschouwing}

De levensbeschouwelijke situatie van Nederland lijkt in vele opzichten op die van de buurlanden Duitsland, Groot-Brittannië, Frankrijk en België. De ruimte voor verdere secularisering moet als beperkt worden beschouwd, omdat deze groep van landen reeds sterk geseculariseerd is.

In Nederland heeft de buitenkerkelijkheid een hoog niveau bereikt, $64 \%$ in 2004. De groei van de islam, de toename van de 'migrantenkerken' het gestegen ledental van kleine orthodox-protestantse kerkgenootschappen en de ontwikkelingen van de Pinkstergemeenten en de Evangelische beweging zijn onvoldoende geweest om het tij te keren.

De ontwikkeling van de buitenkerkelijkheid onder generaties doet vermoeden dat de buitenkerkelijkheid de komende 20 jaar vertraagd zal groeien. De buitenkerkelijkheid onder de respondenten, die tussen 1960 en 1988 waren geboren was namelijk van alle generaties het hoogst, maar vertoonde een tendens tot daling. Volgens de resultaten van een logistische regressie zal in 2020 naar schatting $28 \%$ van de bevolking lid van een kerkgenootschap of van een religieuze groepering zijn. $10 \%$ is dan rooms-katholiek en $8 \%$ is islamiet. De PKN omvat $4 \%$ van de bevolking en $7 \%$ behoort tot de overige kerkgenootschappen.

Heden ten dage wordt de invloed van de kerken op andere maatschappelijke organisaties niet langer gewenst. Bij het onderwijs en in de politiek is er waarschijnlijk sprake van onverschilligheid. Het maakt velen niet meer uit wie een bepaalde dienst levert, als het maar goed gebeurt.

De betekenis van het christelijk geloof voor de waarden komt nog tot uiting in het gezin en medische ethiek. Andere belangrijke terreinen, zoals de economie en de inrichting van de samenleving staan buiten de invloedssfeer van de religie. Het aantal mensen dat van de kerk steun verwacht bij problemen in het persoonlijk leven en sociale problemen is beperkt.

De teruggang in het aantal mensen dat traditionele leerstellingen onderschrijft is in een aantal gevallen gestopt. Het geloof in een leven na de dood, in hemel en hel en in wonderen hebben na 1991 zelfs wat meer aanhangers gekregen. De verzwakking van de adhesie voor het feitelijk bestaan van Adam en Eva, voor een strikte interpretatie van de bijbel en voor de zin van het gebed zette zich echter voort. Over het algemeen treden deze ontwikkelingen op bij kerkleden en bij buitenkerkelijken, in het bijzonder bij de jongere generatie (geboren na 1960) van beide categorieën. Dit wijst op een verandering van de tijdgeest. Er groeit wellicht een voorkeur voor algemene levensbeschouwelijke ideeën, die ook in andere tradities dan de christelijke aan te treffen zijn. Meer leerstellige opvattingen en letterlijke interpretatie worden nog steeds in toenemende mate afgewezen. 
Er is een aanwijzing voor dat de kerkleden qua opvattingen geselecteerd raken. Terwijl de aanhang voor de strikte interpretatie van de bijbel, inclusief het scheppingsverhaal (Adam en Eva) onder alle kerkleden verminderde, hield de jongere generatie kerkleden daar juist aan vast. Deze generatie was eveneens van mening dat men zich aan alle regels van de kerk moest houden. Naar alle waarschijnlijkheid zal het christelijk geloof in de toekomst worden beleden in een betrekkelijk groot aantal, maar verder kleine kerkgenootschappen.

Nederlanders noemen zich met enige graagte een religieus mens, ook al geloven zij weinig of niets. Het begrip religie staat hier dus nog in enig aanzien, zonder dat dit veel consequenties heeft. Buitenkerkelijken, die zich aangetrokken voelen tot het christelijk geloof en tot alternatieve denkbeelden kan men als 'zoekers' beschouwen. In 2002 ging het om 12\% van de bevolking. Dit percentage is internationaal gezien hoog, maar niet hoog genoeg om van een 'religieuze golf te spreken, zoals in de jaren negentig werd gedaan. Ook al zijn wij hier sceptisch gestemd, het valt niet te ontkennen dat het geloof in religieuze wonderen is toegenomen tot een merkwaardig hoog niveau (43\% van de bevolking in 2002). Ratio en wetenschap zijn voor veel mensen dus niet alles, de behoefte aan een betoverde wereld blijft zich stellen. Dit heimwee is zo te zien eeuwig. De 'hertovering' is echter niet volledig. Niets wijst er op dat men de verworvenheden van de moderne techniek afzweert, men wil het wonder er bij.

De ontwikkelingen wijzen er op dat de secularisatie vertraagt. Het begrip raakt derhalve achterhaald. Het is wellicht ook te ongenuanceerd om goed bruikbaar te zijn. Belangrijke ontwikkelingen, zoals de ontkerkelijking en de tanende invloed van kerk en godsdienst op de maatschappelijke instituties hebben hun beslag gekregen of zullen dat in de komende jaren krijgen. Dit betekent echter niet dat ongodsdienstig denken en rationalisme volledig triomferen. Er lijkt een samenleving te ontstaan, waarin het christelijk geloof zodanig is veralgemeend dat het moeilijk van andere religieuze tradities is te onderscheiden en waarin de behoefte aan niet-rationele mogelijkheden zich blijft manifesteren. De invloed van de individualisering is wellicht in dit complex te bespeuren. Secularisatie en geseculariseerd zijn nog steeds bruikbaar als mantelbegrippen en als gemakkelijke aanduidingen. Wij doen er echter goed aan om afzonderlijke ontwikkelingen apart te analyseren om tot een genuanceerd beeld te komen. 


\section{Literatuur}

Becker, J.W. en R. Vink (1994). Secularisatie in Nederland, 1966-1991. Rijswijk: Sociaal en Cultureel Planbureau (Sociale en Culturele Studies 19).

Becker et al (1997). Secularisatie en alternatieve levensbeschouwing in Nederland. Rijswijk: Sociaal en Cultureel Planbureau (Sociale en Culturele Studies 24).

Becker, J.W. (2003). De vaststelling van de kerkelijke gezindte in enquêtes. $40 \%$ of $60 \%$ buitenkerkelijken? Den Haag: Sociaal en Cultureel Planbureau (Werkdocument 92).

Dekker, G. en H.C. Stoffels (2001). Godsdienst en samenleving. Een introductie tot de godsdienstsociologie. Kampen: Kok (5e druk).

Dekker, P. et al. (2004) Vertrouwen in de rechtspraak. Theoretische en empirische verkenningen voor een monitor. Den Haag: Sociaal en Cultureel Planbureau 2004.

Van Harskamp, A. (2005) Simply astounding. Ongoing secularization in The Netherlands. In E. Sengers (red) The Dutch and their Gods. Hilversum: Verloren.

Kennedy, J.C. (2005) Recent Dutch religious history and the limits of secularization. In E. Sengers (red) The Dutch and their Gods. Hilversum: Verloren.

SCP (2005). De sociale staat van Nederland. Den Haag: Sociaal en Cultureel Planbureau.

\section{Noten}

1 De aanpassing van de kerken aan maatschappelijke ontwikkelingen is een derde aspect van secularisatie (Dekker en Stoffels 2001: 117). Het blijft hier grotendeels buiten beschouwing.

2 De werktitel van het rapport luidt als volgt: Recente Gegevens over Levensbeschouwing in Nederland.

3 De cijfers zijn niet vergelijkbaar met die van tabel 11 . Het jaar van onderzoek is anders en de onderzoeken verschillen in enige mate van opzet.

${ }_{4}^{4}$ De analyse maakte gebruik van de correlaties tussen het oordeel over zichzelf als een religieus mens en kerklidmaatschap, kerkgang en reguliere en alternatieve opvattingen. De correlaties zijn volledig vermeld in de nieuwe SCP-publicatie.

$5 \quad$ Er zijn tegenwoordig adviesbureaus voor rituelen actief. Deze putten hun inspiratie echter uit verschillende tradities, niet alleen de christelijke.

${ }_{6} \quad$ De gegevens zijn verzameld door Prof. dr. H. Stoffels en drs. H.Walinga van de Vrije Universiteit in het kader van het project Institutionele gegevens Nederlandse kerkgenootschappen (INGK-project). Zij werden onder meer gepubliceerd in De sociale staat van Nederland 2005 van het Sociaal en Cultureel Planbureau (SCP 2005: 186-187).

7 De gegevens zijn verkregen met de zogenaamde tweetrapsvraag naar de kerkelijke gezindte, die zoals bekend een vrij hoog percentage buitenkerkelijken oplevert (Becker 2003). Dit neemt niet weg dat de trend op dezelfde manier verloopt zoals uit gegevens uit andere bron, vooral de volkstellingen en bijpassende schattingen kan worden opgemaakt. 
8 In de onderzoeken van Culturele Veranderingen in Nederland worden personen van 16 jaar en ouder geënquêteerd.

9 Zelfs 6\% islamieten in de populatie levert op een steekproef van 2000 personen, van wie ruim de helft buitenkerkelijk een geringe trefkans op. Bovendien laten de interviewers het gesprek bij taalmoeilijkheden niet doorgaan.

${ }^{10}$ De betreffende cijfers zijn ter beschikking gesteld door Dr. Nico Landman van de Universiteit van Utrecht.

${ }^{11}$ De resultaten worden gepubliceerd in de nieuwe studie van Becker en De Hart.

${ }_{12}$ Er wordt van de bijbel gevraagd in hoeverre de respondent deze beschouwt als het woord van God: helemaal, gedeeltelijk of helemaal niet. Over Adam en Eva wordt gevraagd of de respondent denkt dat zij echt bestaan hebben. 